\title{
Çağdaş Kapitalizmde Başkaldırı Öznelliği: Demolition (2015)
}

\author{
Murtaza Talha Altınkaya*
}

$\ddot{O} z e t$

Guattari "Chaosmosis" isimli metninde kapitalizmin en önemli üretiminin öznellik üretimi olduğunu belirtir. Zira bu öznellik üretimi ona göre kapitalizmin hem yönetilebilirliği hem de sistemi devam ettirebilmesi için gereklidir. Fakat Guattari için (Lazzarato da bu tezi sürdürür) sorun öznelliğin üretilmesi kadar nerede ve nasıl üretildiğidir. Öznellik artık eskisi gibi çoğunlukla Aile ve Din gibi kurumlarda üretilmez. Lazzarato'nun deyimiyle "toplumsal makineler" için üretilen öznellikler globalleşen dünyanın da etkisiyle artık daha çok tüketim, iletişim, sosyal medya, sinema gibi alanlarda üretilmektedir. Görsellik üretiminin olduğu her alan aynı zamanda öznellik üretiminin de alanıdır. Bu bağlamda anaakım sinema ürettiği özneler ve öznelliklerle bireylerin bilinçlerine hatta Lazzarato'nun ifade ettiği haliyle "birey-öncesi bileşenlerin, algı biçimlerinin hissetme, görme, düşünmevs. biçimlerine" seslendiği söylenebilir.

Filmlerde inşa edilen anlatı tarzı ve yaratılan karakterlerle seyirciye iletilen 'özne' olma durumu her zaman kapitalist öznelliğe hizmet etmediği gibi zaman zaman da o öznellik eleştirilir. Her ne kadar bu tarz filmlerin sayısı az olsa da son zamanlarda bu örneklere sıklıkla rastlanmaya başlanmıştır. Bu filmler genellikle bireyin çağdaş kapitalizmde içinde bulunduğu durumu resmetmekle kalmayıp, Jacques Ranciere'in belirttiği gibi "öznel bir özgürleşmeye radikal bir başkalaşıma" yol açarak yeni öznellik formları inşa etmeye çalışmaktadır. Bu anlamda 2015 yapımı "Demolition / Yön: Jean-Marc Vallée" filmi "toplumsal makineler" için üretilen öznellikleri eleştiren, tüm bu yapıyı yıkmakla kalmayıp özneyi bir boşluğun içerisinde bırakan önemli örneklerden birisidir ve film bu bağlamda irdelenecektir.

Anahtar Kelimeler: Sinema, Öznellik, Deleuze, Lazzarato, Demolition

ORCID ID : 0000-0003-2872-5532

E-mail : talhaaltinkaya@gmail.com

DOI: 10.31122/sinefilozofi.515245

Geliş Tarihi - Recieved: 20.01.2019

Kabul Tarihi - Accepted: 20.02.2019 


\title{
Revolt Subjectivity in Modern Capitalism: Demolition (2015)
}

\author{
Murtaza Talha Altınkaya*
}

\begin{abstract}
Guattari states in his text Chaosmosis that the most important production of capitalism is the production of subjectivity. According to him, the production of subjectivity is necessary for both the manageability of capitalism and the continuation of capitalist system. But for Guattari (Lazzarato also continues this thesis) the problem is the production of subjectivity as well as where and how this subjectivity is produced. Subjectivity is no longer produced in institutions such as Family and Religion. In the words of Lazzarato, the subjectivities produced for 'social machines' are now produced with the help of the globalizing world in areas such as consumption, communication, social media and cinema. Every field where visual production is produced that is also the area of subjectivity production. In this context, the mainstream cinema, along with the subjects and subjectivities that own produces, speaks to the consciousness of individuals or (as Lazzarato expresses) even to the 'feeling, vision and ways of thinking of pre-individual components, perception forms etc.'

The subjectivity which transferred to the spectator with help of narrative style and the characters created in the films does not always serve capitalist subjectivity; sometimes, this subjectivity is criticized. Although the number of such films is small, these examples have been frequently encountered recently. These films not only depict the situation of the individual in modern capitalism but also try to construct new forms of subjectivity, as Jacques Ranciere points out, by causing a radical metamorphosis, a subjective liberation. In this sense, 'Demolition' (2015, Director: Jean Marc Vallee) is a film that not only criticizes the subjectivities produced for 'social machines', but also destroys this whole structure and leaves the subject in a void. Demolition will be examined in this context.
\end{abstract}

Keywords: Cinema, Subjectivity, Deleuze, Lazzarato, Demolition

ORCID ID : 0000-0003-2872-5532

E-mail : talhaaltinkaya@gmail.com

DOI: 10.31122/ sinefilozofi.515245

Recieved - Geliş Tarihi: 20.01.2019

Accepted - Kabul Tarihi: 20.02.2019 


\section{Giriş}

Öznelik üretimine odaklanan bu makalede kapitalizm hem yönetimsellik hem de sistem olarak inşa ettiği öznenin içinde bulunduğu durumlar ve bu öznelliklerin üretilmesi, tüketilmesi ve devamlılığı ekseninde ele alınacaktır. Öznenin çağdaş kapitalizm açısından moderniteden post moderniteye geçişte ne tarz dönüşümler geçirdiği kısaca incelendikten sonra günümüzdeki konumu büyük bir çoğunlukla Maurizio Lazzarato, Gilles Deleuze, Felix Guattari, Micheal Foucault gibi öznellik üretimi üzerine çalışan yazarların düşünceleri çerçevesinde incelenecektir.

Öznellik kavramının Demolition (2015) filmi üzerindeki işlenişi ağırlıklı olarak Deleuze ve Guattari'nin “Toplumsal tabi kılma" ve "Makinesel kölelik" kavramları çerçevesinde değerlendirilecektir. Film öznesinin (Davis) bu kavramlara (yani tabi kılınması istenen ve kölesi olduğu sisteme) başkaldırısı üzerine bir öznellik inşa ettiği iddiasının yanında Lazzarato, Foucault, Hall gibi yazarların eserlerine başvurarak günümüz toplumundaki öznellik teorileri ele alınacak ve Hollywood Sinemasının zaman zaman da olsa çağdaş kapitalist yaşama muhalif bir şekilde alternatif öznellik biçimlerini ürettiği ileri sürülecektir.

\section{Öznellik Üretimi}

Öznellik, herhangi bir kişinin herhangi bir olay, durum ya da şey karşısındaki öznel fikirler bütününü ifade eder. Modernlik bağlamı içerisinde ise özne kökeni Aydınlanma felsefesine kadar dayandırılan bir düşün varlığıdır. Elbette özne ile ilgili teoriler onun sadece bir düşünce varlığı değil aynı zamanda duyu, his, alg1 ve bütünlüklü olarak bir bilinç varlığ1 olduğunu da yansıtır. Bu anlamda öznellik “ben kimim?” sorusuna verilen (duyguları, fikirleri, hisleri hatta kendimizi ait hissettiğimiz kimlikleri de içeren) yantların toplamını kapsar. Öznellik (Wikipedia, 2018) birçok kaynak tarafından farklı şekilde tanımlanmış 'bilinçlilik, faillik, birey olma durumu', gerçeklik ve hakikatle ilgili merkezi, felsefi bir kavramdır. Bu anlamda özne bir yanılla perspektifler, duygular, inançlar ve arzular gibi bilinçli deneyimlere sahip bir birey anlamına gelir. Diğer yandan özne olan bir şey, geniş anlamıyla başka bir varlığa (bir nesneye) göre hareket eden veya güç kullanan, fail olan bir varlık anlamına gelir.

Özne bu haliyle bir başkasıyla, ötekiyle, diğeriyle kaimdir. Öznenin bakışı, düşüncesi ve fikirleri; özetle bütün bir imgelemi kendi dışındaki dünya aracılığı ile oluşur. Eyleme kapasitesi olarak, öznenin dışındaki olanaklılıklar, varlıklar olmazsa özne yani "ben” inşa olamaz. Fakat ben'in inşası felsefecilerin (sosyologların, psikologların, teorisyenlerin) de belirttiği gibi yeterince karmaşık bir konudur.

Örneğin Nick Mansfield (2006, s. 11) özne ve hayatı “kim” in yaşadığ 1 sorununu modern toplumlar bağlamında Derrida üzerinden kavrar ve bazı sorular sorar: "Ben" sözcügüüü söylediğimde neye gönderme yapmaktayım? Benim kendilik duyum nereden gelir? "Benden mi kaynaklanır yoksa kendiliğinden mi ortaya çıkar? Ben sözcügüünü kullandığımda onu sizin kullandığınız anlamda mı kullanıyorum? Kendi mevcut benim, patronum, ailem, arkadaşların, sosyal güvenlik sistemi, sevdiğim biri ya da sokaktaki tehlike gibi farklı biçimler içinde ve karşısında "Ben”, farklı mıyım?" “Ben” (yani bütün öznelliğimizi ifade ve dil dünyasında inşa etmiş olduğumuz kavram) Mansfield için çok biçimsel ve alabildiğine soyut kavramlar ve çok canlı, yoğun duygular arasında bir buluşma noktası olan bir kavramdır. 
Öznenin genel olarak özetlemek gerekirse başlıca dört kullanıma sahip olduğu söylenebilir. Mansfield'e göre;

“ - Birincisi cümleyi başlatan ya da sürdüren ilke, gramer öznesidir. "Ben" sözcü̈̆̈̈nü, öncelikle yaşamımı olarak ifade ettiğimiz ve birlikte edindiğimiz deneyimlerin, duyguların ve eylemlerin kaynağı anlamında bilir ve kullanırız. Göreceğimiz gibi, bu öznellik tipi büyük ölçüde aldatıcıdır: o en basit ve dolaysız bir şahsiyet duyusu siparişi gibi görünür fakat sözcüğü dilimizin öteki kullanıcılarıyla paylaştı̆̆ımız için, bizi devasa, değişken hatta sonsuz bir tarih öncesi anlam yapım ağına sürükler.

- İkincisi meşru politik özne'dir. Çeşitli biçimlerde, bizim toplumsal etkileşimimizin sınırlarını tanımlayan ve sözde en önemli değerlerimizi somutlaştıran anayasa ve yasalar, sabit güçlerin ve kodlarm aktörleri ve icracıları olarak bize hukukun, devletin ve bir karlın öznesi olduğumuzu anlatır. Liberal demokratik toplumlarda, en azından kuramsal olarak, bu öznellik sinfflaması bizim bireysel haklara saygılı olmamızı ve dürüst yurttaşlar olmamızı talep eder. (...)

- Üçüncüsü felsefi özne'dir. Burada 'ben' hem bir analiz nesnesi hem de bilgi ve hakikatin temelidir. (...) Örneğin Immanuel Kant felsefi özne problemini tanımlayan konuların bir dökümünü yaptı: dünyayı nasıl bilebilirim? Dünyada eylemde bulunduğumu nasıl bilebilirim? ve dünyayı nasıl yargılayabilirim? Burada özne ahlakın, hakikatin ve anlamın merkezine yerleştirilmektedir.

- Dördüncüsü de insani bir varlık olarak özne'dir. Şahsiyet analizimizin, politikanın, felsefenin ve dilin terimlerine göre ne kadar ayrıntıl olursa olsun, karmaşık, tutarsız ve tıka basa doldurulmuş bir dünyada ortaya çıkan ve düzene, mantığa ve sisteme meydan okuyan zengin ve dolaysız bir deneyimin belirgin odağı olarak kalırız. (...) Genelde ölçülü ama yine de serüven dolu bir yolculuk içinde deneyimlenen, çoğunlukla tutarl ve amaçh gibi gördüğümüz, ucu açık ancak bildik bir yaşam süreriz. Genel olarak kişiliğimiz ya da şahsiyetimiz olarak algıladığımız şey, bu bitmemiş ancak tutarl öznelliktir." (Mansfield, 2006, s. 14-15)

Getirdiği dört farklı özne yaklaşımının sonucunda bir soykütük oluşumu için çabalayan Mansfield için öznelliğin ne olduğu konusunda bir netlik ve sonuç söz konusu değildir. Özne onun da belirttiği gibi Freud ve Lacan'ın çalışmalarından sonra Aydınlanmanın kendisine tahsis ettiği "akıl" varlı̆̆ olma durumunun ötesinde duygu, istenç ve arzu varlı̆̆ı olarak ele alınmaya başlanır. Bu anlamda Özne "daima dışındaki bir şeye -bir düşünceye ya da ilkeye veya öteki özneler topluluğuna bağhldır. Etimolojik olarak, özne olma, 'alta yerleşmiş (ya da alta itilmiş) olma' anlamına gelir. İnsan daima bir şeye göre özne ya da bir şeyin öznesidir." (Mansfield, 2006, s. 14)

\section{Modern Özneden Post-Modern Özneye (Faillik Sorunu)}

Her ne kadar modern kavramı kökenlerini "modus" yani “çağa özgü" kavramından alsa da modernliğin temelleri (Rönesans hatta 11.yy'a götürülmekle birlikte) Aydınlanma çağında bulunur. İnsanları orta çă̆'ın "karanlık" dünyasından kurtaran ve "1şıklar yüzyılı" olarak tanımlanan Aydınlanma çağında dinsel ve mitsel olan şeyler (kimlikler, düşünceler, gündelik hayat, vb.) yerini bilim ve akla bırakmaya başlar.

“Çağdaş insanın çelişkileri ilk kez Aydınlanma Hareketiyle genel insanlık bilincine taşınmıştır. Bu çelişkilerin başında, bilim ile inanç arasındaki çelişki gelir. Bilim ile inanç arasındaki çatışmanın sonunda, bilim, gerek insanın doğaya egemen olmasını sağlayıcı gerekse onun pratik faaliyetini yönlendirici bir araç olarak inanç karşısında üstün gelmiştir." (Buhr, Schroder, \& Barck, 2006, s. 56) 
Yaratılan bu yeni dünya ile birlikte dünyaya egemen olan mitsel düşüncenin yerini rasyonalite temelli bir düşünce almıştır. Bu bağlamda toplumlar artık doğa ile ilişki kurmak ve doğayı anlamak bakımından ilişkilerini mitsel düşüncenin öğretileri ile değil gözlem, deney ve rasyonelite yoluyla sağlamaya başlar. Merkezinde birey'in (ben'in) ve akıl'ın bulunduğu rasyonalizm için kurulması gereken tüm bu ilişkiler akıl ile ve o akıl ${ }^{1}$ aracılığıyla gerçekleştirilecek olan "bilim" ile kurulmalıdır. Zira rasyonalizm bir taraftan bireye aklı ve ölçüyü kullanması buyruğunu iletirken diğer taraftan akıl denen bu kavramın bilim ve felsefe de dahil olmak üzere tüm alanlarda otorite olması üzerine kurulur. Bu otoritenin başında ise kendisini dinsel kabullerden kurtararak ilk kez rasyonel bir "kendilik" olarak inşa eden birey vardır. Descartes'ın “Düşünüyorum o halde varım” sözündeki düşünen birey, 1şıklar yüzyılı ile birlikte var olmaya başlar. Bu anlamda tarihte kendi ayakları üzerinde durabilen, mitsel ve tanrısal buyruktan sıyrılmış öznelliğin ilk inşasının Aydınlanma dünyası ile birlikte var olmaya başladığı ortadadır.

"Ben artık daha fazla, özsel bir amaçla tanımlanmaz ya da bağlanmaz, yalın bir biçimde asli bir doğa ya da telosu gerçekleştirmekle sinırlanmaz. Modern felsefenin karakteristik beni, bilincin soyut ve cisimleşmemiş öznesidir. Descartes'ın bu bene ilişkin açıklaması onun bilgi için şüphe edilemez temeller bulma teşebbüsünden doğar. O yalnızda kendilerinden şüphe etmenin imkansız olduğu inançlardan emin olurken, ünlü kökten şüphecilik ya da şüphe yöntemini izler. Bu yöntemle Descartes hemen, kesin olan tek şeyin "varım, varoluyorum" olduğu sonucuna ulaşır." (West, 1998, s. 27-28)

Descartes'ın ulaştığı ve ürettiği "ben"/"özne" basit bir şekilde sadece kuşkuları aracılığıyla var olan bir varlık olarak değil fakat zamanda tarihi inşa eden, hatta "kendilik"i her şeyin ötesine yerleştiren bir anlam verme varlığı olarak inşa edilmiştir. Mansfield'den aktarmak gerekirse;

\begin{abstract}
"Bilginin anahtarı, insanın dünyadaki yeriyle ilgili yeni anlayışın başlangıcın gösteren "ben" sözcüğüule ilgili formülasyonda bulunmuştur. Her ne kadar Descartes'ın düşünümünün vardı̆̆ yer, Tanrı'ya inancını yeniden güçlendirmiş olsa da, onun manivelası kendilik tanımıdır. Bu yüzden Descartes'da Aydınlanma düşüncesinin taptı̆̆ı ve vurguladığı iki ilkeyi de birlikte buluruz: ilki, dünyadaki tüm deneyimin ve bilginin temeli olarak kendilik imgesi (Ben her şeyden önce ben Varım) ve ikincisi, dünyaya düzen vermek için kullanilabilecek rasyonel yeti tarafindan tanımlanan biçimiyle kendilik (anlam veriyorum)." (Mansfield, 2006, s. 26)
\end{abstract}

Demek ki insan Aydınlanma ile birlikte yalnızca kendi ayakları üzerinde durmaz aynı zamanda kendi inşa etmeye başladığı dünya içerisinde tarihin de yapıcısı konumuna gelir. Özne olma anlamında insan modern toplumlarla birlikte Foucault'a göre aslında iktidarın eylemlilik kipinin taşıyıcısıdır, iktidar bireysel ya da kolektif bir ilişki tarzı geliştirmez. “İktidar bazılarının başkalarının üzerinde eylem kipidir. Kuşkusuz bunun anlamı, iktidar diye bir şeyin olmadığı; global olarak yoğunlaşmış ya da dağılmış biçimde var olacak bir iktidar olmadığıdır: sadece "birilerinin” "başkalarına” uyguladı̆̆ı iktidar vardır; iktidar, elbette kalıcı yapılara dayanan bir dağınık imkanlar alanına kaydolmuş olsa bile yalnızca edimde vardır." (Foucault, 2014, s. 73-74)

1 Aydınlanmanın yaratmış olduğu bu akla sert eleştiriler henüz 20.yy'ın başlarında yapılmaya başlanmış ve özellikle Frankfurt Okulu düşünürlerinin bir kısmının eserleri ve çalışmalarının odağını sadece bu (kendilerinin hastalıklı olarak adlandırdıkları) akıl almıştır. Bu anlamda Max Horkheimer'ın Akıl Tutulması eseri en önemli kaynaklardan birisidir. (Horkheimer, 2018) 


\begin{abstract}
"Bu iktidar biçimi bireyi kategorize ederek, bireyselliğiyle belirleyerek, kimliğine bağlayarak, ona hem kendisinin hem de başkalarının onda tanımak zorunda olduğu bir hakikat yasası dayatarak doğrudan gündelik yaşama müdahale eder. Bu, bireyleri özne yapan bir iktidar biçimidir. Özne sözcüğ̈̈nün iki anlamı vardır: Denetim ve bağımlilı yoluyla başkasına tabi olan özne ve vicdan ya da özbilgi yoluyla kendi kimliğine bağlanmış olan özne. Sözcüğün her iki anlamı da boyun eğdiren ve tabi kulan bir iktidar biçimi telkin ediyor." (Foucault, 2014, s. 63)
\end{abstract}

Bir akıl varlığı olarak insan aydınlanma ile birlikte tarihin öznesi konumuna getirilmiş fakat bu durum yanında bir özne-iktidar ikilemini de getirmiştir. Özne Foucault'un da yukarıda belirttiği gibi eylem kipliğinin taşıyıcısı olarak hareket etmekte ve kendi özgür kararlarını yerine getirmektedir. Fakat burada artık özneyi anlamak demek iktidarı anlamak demektir. Modern iktidar Foucault'cu anlamda kendisini rasyonel bir varlık olan öznelerin faillik süreçleri üzerine konumlandırır. Özne düşünceleriyle, hissettikleriyle ve eyleme geçirdikleriyle "biyo-politik" bir varlık olarak iktidarı inşa etmektedir.

Aynı iktidar ve öznellik eleştirisi günümüz teorisyenleri tarafından da sürdürülür. Rasyonalite yoluyla özgürlüğüne kavuşmuş ve bir eyleme kapasitesine sahip olan birey henüz 19.yy'da sanayileşmenin getirdiği göç ile birlikte bir "kitle”ye dönüşür. Kapitalizmin "düzenlediği" toplumsal yapı içerisinde özne eyleme kapasitesine sahip gibi görünmekle birlikte her zaman bir tahakküm altındadır. Bu tahakküm psikanalitik teoriye göre bilinçdışı üzerinden, Althusser'e göre iktidarın çağırması üzerinden ya da Kristeva'ya göre toplumsal cinsiyet ve cinsel kimliklerimiz üzerinden kurulur. ${ }^{2}$ Her ne üzerinden kuruluyor olursa olsun günümüzde öznelerin tercih ettikleri ve kendilerini "hissettikleri" kimlikler ve bu kimlikler aracılığıyla oluşan öznellikler bir seçme ve faillik yanılsaması üzerine kuruludur. Hall'ın (2004, s.5) ifadesiyle günümüz özneleri geniş çeşitlilikte otorite figürleri tarafından kimliklerini yeniden düşünmeye, ifade etmeye ve açıklamaya teşvik edilmektedir. Bu özneler ebeveynleri, rehberlik öğretmenleri, en çok satan kişisel gelişim kitapları, talk şov sunucuları ve hatta reklamcılar vasıtasıyla pahalı bir araba satın alarak, kilo verme programına girerek ya da yeni bir saç rengini deneyerek, "kendini" ifade etmenin farklı bir biçimini denemeye teşvik ediliyorlar. Bu noktada eğer öznelerin (bizlerin) bir iradesi varsa bizler yaygın bir biçimde "benliklerimizi" yaratma ve yeniden inşa etme özgürlüğüne sahip olduğumuza inandirıliyoruz.

$\mathrm{Bu}$ anlamda herhangi bir konuda seçim yapma genellikle modern özneler için bir yanılsamadır. "İnsanlar özgür iradelerine sarsılmaz bir şekilde inanırlar. Fakat onlar siyasi görüşlerini, elbiselerini, tavırlarını, kimliklerini, kendi elleriyle yazmadıkları bir menüden seçiyorlar. Onlar anlamadıkları ve hatta bir bilinci bile olmayan güçler tarafından mecbur bırakılıyorlar. Ancak seçim yapma yanılsaması bile çok büyük bir sosyal öneme sahiptir."(Aktaran Hall, 2004 s.4)

Bu anlamda özellikle 1968 yılında yaşanan olaylardan sonra öznenin ve yeni dünya düzeninde öznelliğin üretiminin nasıl işlediği tartışılır hale gelmiştir. Bu tartışmanın odağında

2 Öznellik üretimi ve bu konunun tartışılması, burada ismi geçen filozofların yanında onlarca teorisyeni de kapsayan bir tartışmadır. Descartes ve "ben" in inşası ile erken modernlikte başlayan tartışma kaba hatları ile Marx, Hegel, Nietzsche, Freud ve yeni yüzyıl ile Horkheimer, Adorno, Marcuse, Fromm, Lacan, Althusser, Foucault, Ricoueur, Haraway ve burada adını sayamadığımız onlarca teorisyeni de kapsar. Ayrıca konu günümüzde felsefi ekseninin ötesinde Teknoloji, Toplumsal Cinsiyet, Cinsellik, Irk, Post Sömürgecilik gibi kavramları da barındıracak şekilde çok geniş bir eksende tartışılmaya devam etmektedir. 
ise başlıkta da belirtildiği gibi “faillik" (agency) sorunu vardır. Lacan'ın çalışmaları ile birlikte özne aydınlanmanın kendisine atfettiği gibi bütünlüklü, kendi ayakları üzerinde duran, kendisiyle özdeş bir akıl varlığı olarak görülme biçimini yitirir. Aksine özne kültür içerisinde değişir, dönüşür ve psikanalitik bağlamda aslında bir yarılış/parçalanma, paradoksal bir şekilde bir "özne olamama", tamlık sergileyememe yani salt bir yabancılaşma sürecinin içerisine girmiş olur. Aynı şekilde Althusser' in çalışmalarında özne devlet ve onun aygıtları tarafından düzenli olarak çağrılır. Yukarıda da belirttiğimiz gibi Foucault için özne sürekli olarak iktidar ile temas içerisindedir. Bu temas insan ilişkilerinde, mimaride, hareket tarzlarında ve bizatihi eyleme tarzlarında rahatlıkla gözlemlenebilir.

Böylelikle günümüzde de öznellik teorilerinin "faillik" yani eyleyenin kim olduğu sorunu etrafında tartışıldığı söylenebilir. Fail durumunda olan öznelerin eylemi gerçekleştirdiği konusunda herhangi bir tartışma yoktur fakat o eylemi gerçekleştirme istencinin nasıl oluştuğu, bu istencin modern kapitalist toplumlarda öznelere nasıl ulaştı̆̆ı ve özneleri nasıl inşa ettiği konusu teorisyenlerin en fazla üzerinde durduğu konulardan biridir. Özneler eyleyen olarak faildir fakat eyleme geçirdiği şeyleri nasıl istediği ya da sahip oldukları arzular bağlamında öznelliklerini nasıl oluşturdukları konusu onların gerçek fail olup olmadıklarını düşünmemize neden olur. Bu anlamda aslında (her ne kadar eyleyen özneler gibi gözükse de) paradoksal bir şekilde failin yani öznenin kendisi de kapitalist sistem olmaktadır.

Andrea Rossi'nin belirttiği gibi; "nihayetinde, yönetmeye çalıştığı özneleri hiç dokunmadan bırakan tek bir politik sistem yoktur çünkü politikanın en başta gelen görevlerinden biri tam olarak erkekleri ve kadınları, varolan bir toplumsal ve ahlaki düzenin içinde yaşamaları ve ona uyum sağlamaları için "eğitmek"tir. İnsanın ruhu, politik varoluşu içerisinde bir bakıma sürekli olarak tehlike altındadır." (Rossi, 2018, s. 129)

Lazzarato (gerçekleşmeye devam eden) bu tehlikeyi Deleuze ve Guattari'den yola çıarak "toplumsal tabi kılma" ve "makinesel kölelik" kavramlarıyla açıklar ve bunun üzerinde durulması gerektiğini savunur zira ona göre kapitalizm "otomobil sanayinin yeni seri arabaları piyasa sürmesi gibi, (öznel) modeller piyasaya sürer. Kapitalist politikanın temel projesi sahiden de ekonomik, teknolojik ve toplumsal akışların öznellik üretimiyle eklemlenişine dayanır. O kadar ki politik ekonomi “öznellik ekonomisi”ne özdeştir." (Lazzarato, 2016, s. 8)

Bu noktadan sonra Mansfield'in Baudrillard'dan mülhem ifade ettiği gibi; özne kişinin artık ben diyebildiği bir noktaya değil tersine ben demesinin ya da dememesinin öneminin olmadığı bir noktaya gelmesi karşısında bir çıkmaz içerisindedir.

Zira özne Aydınlanmayla birlikte elde etmiş olduğu gerçekliği belirleme gücünü ve edimini Deleuze'cu anlamda büyük kapitalist makineye devretmiştir. Modern özne gerçekliği belirleyerek muktedir olmak isterken aslında kapitalist iktidarı yeniden inşa eder. Zira günümüz kapitalizmi açısından öznelliğin inşası diğer metaları üretmekten çok da farklı değildir. Hatta bir özne tasarlamak/üretmek sistemin devamlılı̆̆ını sağlamak adına tüm metalardan önce üretilmesi gereken bir ön gerekliliktir. “Guattiriye göre öznellik, diğer bütün metaların üretimini koşulladığı ve bu üretime dahil olduğu için kapitalist ürünlerin en temel ve en önemli olanıdır. Öznellik, "niteliği" tıpkı otomobil, elektrik ya da bir çamaşır makinesi gibi düşünülen, geliştirilen ve imal edilen" kilit bir metadır (Aktaran Lazzarato, 2016 s. 60) ve bu metanın devamlılığ1 "makinesel kölelik" ve "toplumsal tabi kılma" makinelerinin işlemesi ile sağlanır. 


\title{
“Toplumsal Tabi Kılma” ve "Makinesel Kölelik" Altındaki "Borçlandırılmış Özne"
}

Lazaratto, Deleuze ve Guattarinin çalışmalarına dayanarak günümüz toplumlarında öznellik üretiminin bu iki kavram etrafında şekillendiği üzerine vurgu yapar. Öncelikle "toplumsal tabii kılma bizi birçok kimlik aracılığıyla öznellikle donatır, bize bir kimlik, bir cinsiyet, bir beden, bir meslek, bir milliyet vb. tahsis eder. Toplumsal iş bölümünün ihtiyaçlarına karşılık olarak, bu yolla bireyselleşmiş özneleri, onların bilinçlerini, temsillerini ve davranışlarını üretir." (Lazzarato, 2016, s. 12) Aslında tabiiyet öznelerin çok da farkında olmadığ1 dil düzeni içerisinde çalışır. Çünkü dil öznelerin hiçbir zaman aşamadığı bir temsil ve anlamlar dünyası yaratır. Özne istese de istemese de bu temsil ve anlamlar dünyasının içerisinde varolur.

\begin{abstract}
“Kapitalizm öznelliğin üretimi ve deneyimini (ahlakın modern soybilimi), bireyselleşmiş özneyi ("toplumsal tabii kılma") ve onun görünüşte karşıtı olan, öznelliğin çözülüşünü [desubjectivation] ("makinesel köleleştirme") birlikte dokuyan iki farklı dispozitif aracılı̆̆ıyla örgütler. Dolayısıyla kapitalizmin öznellik üzerindeki etkisi iki yönlüdür. Tabi kılma; (politik ve dilsel) temsil, bilgiler, söylesem, görsel uygulamalardan geçen, onlarn seferber eden ve "hukuk kişileri", "politik kişiler", kısaca "kişiler", "ben"ler, bireyler üreten yönetim tekniklerini içerir. Toplumsal tabi kılma, bizi bireyselleşmiş özneler olarak üreterek, bize bir kimlik, cinsiyet, bir meslek, bir uyruk vs. tahsis eder. Kimsenin kaçamayacağı, gösteren ve temsili bir semiyotik tuzak inşa eder. Çă̆daş kapitalizmde bu süreç ve teknikler, gerçekleşmelerini, her birimizden kendi "eylem" ve "davranış"larından sorumlu ve suçlu bir özne yaratan "insan sermayesi"nde bulur. Her türlü kişisel bağımlilıktan "kurtulmuş olma" anlaminda "özgür özne", kendinin girişimcisi figüründe ve "egemen" konuma yerleşerek sinırsız ürün çeşitliliği arasından seçim yapan tüketici figüründe gerçekleşir." (Lazzarato, 2015, s.154-155)
\end{abstract}

Öznelerin kapitalizmin inşa etmiş olduğu bu tabiiyet düzeninden, bu semiyotik dil evreninden kaçma olasılığı yok gibidir. Kullanıcı ve tüketici özneler olarak televizyon makinasına ya da günümüzde telefon, tablet ve diğer tüm mobil dijital teknolojiler üzerinden büyük internet makinasına tabi kılınırız. Bu anlamda Lazzarato'nun yukarıda belirttiği gibi öznenin bilinci ve temsilleri sayesinde programlarla, imajlarla ve anlatılarla bir özne olarak özdeşlik kurarız. "Öte yandan, "televizyon izleyicileri” olarak artık ne tüketici veya kullanıcı ne de televizyonu 'yaptı̆̆g' varsayılan özneler olan ama öte yandan makineyi bu şekilde üretip kullanarak, artık makineyle bağlantısı olmayan içkin tamamlayıcı parçalar haline geldikleri ölçüde "köleleştirilmişizdir." (Lazzarato, 2016, s.49)

Özne bu evrenden her çıkma girişiminde (aslında Lacancı anlamda dışsal gerçekliğe erişmek isteğinde) büyük kapitalist makinanın üretmiş olduğu makinesel kölelik düzenine yeniden temas eder. Zira makinesel köleliğin çalışma prensibi toplumsal tabi kılmadan farklıdır. Herşeyden önce makinesel kölelik bireyleşmiş bir özne ve toplumsal tabiyete ihtiyaç duyar. Bu tabii olma durumu sağlandıktan sonra artık makinesel köleliğin işlemesi için dilbilimsel ya da göstergesel bir öznellik üretimine ihtiyaç kalmaz.

Makinesel kölelikte, "birey artık "bireyleşmiş özne”, "ekonomik özne” ya da sistemin genellikle inşa ettiği gibi "vatandaş" veya "yurttaş" olarak kurulmaz. Bunun yerine birey artık, "şirket" asamblajı, "finansal sistem" asamblajı, medya asamblajı, refah devleti asamblajı ve onun kolektif kurumlarının (okullar, hastaneler, müzeler, tiyatrolar, televizyon, internet vb.) 
içerisindeki bir dişli, bir çark ve tamamlayıcı bir parça olarak düşünülür." (Lazzarato, 2016, s. 25)

İnsanlar Deleuze ve Guattariye göre (Deleuze \& Guattari, 1987, s. 456-457) kendi kendilerine ya da başka şeylerle, örneğin hayvanlarla ya da diğer araçlarla, oluşturmuş oldukları daha yüksek bir birliğin kontrolü ve yönetimi altında oluşturdukları bir makinenin parçaları oldukları için "makinesel kölelik" vardır. Dışarıda bakıldığında insan artık makinenin bir bileşeni değil, bir çalışanı bir kullanıcısı gibi görünür. Makineye maruz kalır ve köleleştirilemez gibi görünür ancak günümüz toplumları açısından değerlendirildiğinde antik çağın özel köleliğinin veya feodal köleliğin aksine, bu kölelik sistemi "genelleştirilmiş kölelik" olarak adlandırılır.

Örneğin televizyon izleyicileri kendilerini "eyleyen özneler" olarak görseler de aslında makinesel köleliğe hizmet eden hizmetçilerdir. Deleuze ve Guattari (Deleuze \& Guattari, 1993, s. 90) kendisini anlatım öznesi olarak kabul eden sözce öznesinin aslında televizyon karşısında onu kullandığı ve tükettiği oranda televizyona kul köle olduğu belirtir. Teknik makina bu anlamda iki özne arasında araçtır. Televizyon seyircileri ne tüketim, ne kullanım, ne de onu "yapmaları" gereken özneler olup, feedback veya geriye dönüşlerin "girişlerin» ve «çıkışların» içerideki bileşim parçaları olmalarından dolayı televizyon makinesi için hizmetçiler haline gelirler. Geri dönüşler, makinayı kullanma veya üretme biçimine değil, makinaya aittir. Makinesel hizmetçilikte, kimilerinin insani, kimilerinin mekanik olduğu haber alışverişlerinden ve değişikliklerden başka bir şey yoktur.

Sistem içerisinde insanların (eyleyen öznelerin) büyük kapitalist makinenin kendi devamlılığı için yaratmış olduğu makinesel parçaların işlevselliklerinden çok da farkı yoktur. Özneler "özgür" bir biçimde bir fiili yerine getirdiklerinde aslında büyük bir makinesel kölelik düzenin devamlılığını sağlayan önemli bir makinesel parça olduklarının farkında değildirler. $\mathrm{Bu}$ anlamda günümüz toplumları için faillik problemi ile kast edilen sorun tam olarak bu noktaya oturur. Makinesel kölelik içerisinde öznellik (toplumsal tabii kılmanın aksine) temsili olmayan bir şekilde bir işlevsellik üzerine kurulu olarak de-sübjektivite ${ }^{3}$ vasıtasıyla inşa edilir.

"1920'lerde reklamcilığın yükselişi ve sonrasında televizyonun icadıyla, içinde Google ve Facebook'un parlak başarı elde ettiğgi daha öncekilere göre çok daha iyi organize edilmiş bir makine geliştirilmiştir. Bu makine, bir pazarlama aygıtı olarak işlev göre muazzam bir veri tabanı ortaya çıkartmışıır. "Boş zamanı"mızı nasıl geçireceğimizin yanısıra davranışlarımız, harcamalarımız, okuma alıskanlıklarımız, beğendiğimiz filmler, zevklerimiz, kıyafetlerimiz ve beslenme tercihlerimize dair milyonlarca veri toplanır, ayıklanır ve satılır. Bu enformasyon verilerin kesişmesi sayesinde oluşan profillerin üretim-tüketim makinelerinden girdi ve çıtıların yedek parçalarını oluşturduğu, "bölünebilir"leri dikkate alır. (...) Akışlar, ağlar ve makineler tarafindan idare edilen bölünebilirler yönetimi, yalnızca bireylerin temsilleri ve bilinçli davranışları üzerinde değil, arzular inançlar ve öznelliğin temsili ikincil gerçekliği üzerinde de etkide bulunur." (Lazzarato, 2016, s. 38)

Böylelikle insan Lazaratto için (2016, s.39) bir taraftan eyleyen özne gibi görünmekle birlikte diğer taraftan "işletmelerin, iletişimin, refah devletinin ve finansın makinesel aygıtları tarafından köleleştirilir; öte yandan da bize kullanıcı, üretici, tv izleyicisi ve benzeriymişiz

3 Desubjectification kavramı Deleuze ve Guattari'nin öznellik tartışmaları içerisinde önem arz eden bir kavramdır zira büyük kapitalist makine öznelere "sen failsin", "eyleyen özne sensin" diyerek seslenirken aslında onları makinesel anlamda köleleştirip de-sübjektiv bir sürecin içerisinde itmektedir. $\mathrm{Bu}$ anlamda faillik (eyleyen olma durumu) paradoksal bir şekilde tersine işlemektedir. 
gibi roller ve toplumsal ve üretime yönelik işlevler tahsis eden bir iktidar tabakalaşmasına tabi kılınırız." Birey gündelik yaşamında tek başına düşünemez ve hareket edemez hale gelir zira kapitalist makinenin kurmuş olduğu büyük bir ağ tarafından kuşatılmıştır. Bu makinesel sistem içerisinde öznenin (her ne kadar tüm öznellik üretimleri "özgürlük ve faillik" üzerine kurulu olsa da) tek işlevi makinanın devamlılı̆̆ını sağlamaktır. Guattari'nin öznelerin bilinçlerinin makinesel asamblaj içerisinde nasıl işlev kazandıklarını tarif etmek için anlattığı araç kullanma örneği dikkate değer bir örnektir.

\begin{abstract}
"Arabayı sürerken öznelliği ve arabanın teknolojik mekanizmalarıyla bağlantılı bir kısmi bilinçler çoğulluğu etkinleştiririz. "Bu düğmeye basmalısın bu pedal ittirmelisin" diyen "bireyleştirilmiş bir özne" yoktur. Eğer biri araba sürmeyi biliyorsa bunun üzerine düşünmeden, düşünümsel bilinci işe katmadan, yaptı̆̆ı şey üzerine konuşmadan ve onu temsil etmeden hareket eder. Arabanın makinesel asambjlajı tarafindan yönlendirilir. Davranışlarımız ve öznel parçalarımı (hafiza, dikkat, algılama vb.) "otomatikleştirilmiştir", tıpkı mekanik (insan-olmayan) parçalar gibi, makinesel, hidrolik, elektronik vb. aygıtlardan oluşan asamblajın bir parçasıdır. Araba sürmek, birbirini takip eden, biri diğerine eklenen, olaylara göre bağlantılı hale gelen ya da bağlantıları kesilen farklı bilinç süreçlerini hareket geçirir. Sürüş esnasında "bazıları ışık seli gibi akan, bazıları da ön plana çıkan birkaç bilinç sisteminin paralel bir biçimde işlev görmesine isim veren" ayakta uyuma durumuna geçer, 'sahte bir uykuya' dalarnz." (Lazzarato, 2016, s. 94-95)
\end{abstract}

Gerçekten de araba kullanan öznenin (ki bu kullanım sadece araba özelinde değil fakat hayatımıza temas eden diğer bütün 'makineler'in kullanımı bağlamında ele alınabilir) araba kullanma eylemi içerisinde yaptığ 1 hareketlerde herhangi düşünümsellik yoktur. Kişi “şimdi debriyaja basmalıyım vitesi yükseltmeliyim, ayağımı hafifçe pedala dokunmalıyım ve vitesi elim aracılığıyla yukarı doğru itmeliyim" cümlesinde özetlendiği haliyle bir düşünsel sürecin içerisine girmez. Bu eylemleri otomatik (kendiliğinden) bir şekilde yerine getirir. Bu noktadan sonra kişinin yaptığı eylemle, arabanın herhangi bir parçasının yaptığı eylem (örneğin direksiyon mili) arasında bir fark kalmaz. Her iki eylemde araba makinesinin asamblaj1 içerisinde yönlendirilir. Bu eylem tüm araba süren sürücüleri de içine alarak düşünüldüğünde büyük ‘bir araba makinesi asamblajı' ndan söz edilebilir.

Ayrıca Guattari harekete geçirdiğimiz bu makinesel asamblajların sabah uyandığımız andan itibaren bizi çevrelediğini ve gündelik hayatımızın neredeyse her anına ve mekanına temas ettiğini belirtir;

\footnotetext{
"Sabahları uyanırım, lambayı açarım ve bir ağı "harekete geçirecek" bir katalizör sağlamış olurum. Sonsuz ağlarmn içinden geçen elektrik akışlarmın izi takip edilirse, nükleer santrallere kadar uzanan bir yol görünecektir. Kahvaltımı hazırladığım sırada duruma bağh olarak ev içi emeği özgürleştiren ya da üretkenliğini artıran makineleri (ocak, buzdolabı, vb.) yar uyanı bir halde konuşma ve insan sesini etkili bir "makinesel" dönüşüme uğratan radyoyu açarım. Ses dünyasının alışageldik mekansal ve zamansal boyutlar askıya alını. Ses algısının dayandığı duyusal ve motor şemalar etkisiz hale getirilir. İnsan sesi, konuşma ve ses yersiz yurtsuzlaşır, çünkü bir bedenle, bir yerle, bir durumla ya da bir alanla olan her türlü ilişkisini yitirir. (...) Dışarı çıkmadan evvel konuşmanın ne zaman ve nerede olacağını öğrenmek için bir telefon konuşması yaparım. Gideceğim yere doğru yola çıkmadan önce, bana emirler veren (şifreni gir, kartını ve paranı al!) ATM'den para çekerim. Ĕ̆er hata yaparsam bu makine bana parayı vermeyi reddeder ve kartımı yutar! (...) Eğer işsizlik veya sosyal yardım çeklerimle ilgili bir problemim varsa 1'e 2'ye veya 3'e basmamı söyleyen bir çağr merkezi ile iletişime geçerim. Aynı şey bir elektrik şirketiyle görüşürken, bir internet sağlayıcısına
} 
kaydolurken, banka hesabımla ilgili bilgi alırken de geçerlidir. Bu ağlarda bir insan bulmak imkansız olduğundan zaman kaybediyor olsam dahi, işleri kendi başıma çözmem gerekir. (...) Süpermarkette, genellikle yarı-zamanlı istihdam edilen bir kasiyerin yapacağı işi bedavaya yaparken, bana zaman kazandıracağı varsayılan otomatik kasa ile cebelleşirim." (Aktaran Lazzarato, 2016, s. 97-98)

Yaşanan deneyim Guattari için modern kapitalizmin her aygitı ve kurumunun işleyişinde görülebilir. Çağdaş kapitalizmde özne bu deneyim içerisinde artık sadece bazı hataları düzeltmek ve büyük asamblajın ana akışının bozulmaması için çalışan büyük dişliyi döndürmeye yarayan küçük bir dişli işlevselliğine sahiptir.

$\mathrm{Bu}$ işlevsellik içerisinde öznelerin bedenleri, duyguları, arzuları şekillendirilir ve bu "her işçiyi mülk sahibi bir burjuvaya" dönüştürmeye uğraşan bir bilinçdışının oluşturulması ile yapılır. Özel şirketler, tüketim, reklam, sinema gibi bireylerin çok sık tükettiği makinesellikler yoluyla bireylerin sadece davranışlarında değil, birey-öncesi bileşenlerin, algı biçimlerinin, hislerinin, düşünme biçimlerinin yönetimi de yatırım yapmaktadır. Bu anlamda şirketler aslında sadece meta üretmezler aynı zamanda dünyalar, öznellikleri, değerler, yaşam biçimleri üreterek bunları bilinçdışıyla donatırlar. Bu Lazzarato'nun “Borçlandırılmış İnsan İmal Etmek" ${ }^{4}$ olarak adlandırdığı bir borçlu özne inşasıdır. Borç şimdi ile gelecek arasına bir köprü kurar: gelecek üzerinde bir önalım hakkı öngörür. Gelecekteki davranışlarını, ücretlerini ve gelirlerini ipotek altına alır. (Lazzarato, 2015, s. 58)

$\mathrm{Bu}$ anlamda kitle iletişim araçları, bilişim, dijital ve robotik teknolojilerin semiyotik üretimleri psikolojik öznellikten ayrı tutulamaz. Toplumsal Makineler (genel bir iş ekipmanı gibi düşünülerek), "teknolojik bilgi ve iletişim makineleri insanın öznelliğinin merkezinde, sadece hafızası ve zekası içinde değil, duyarlılığı, etkileri ve bilinçdışı fantezileri içinde de çalışır." (Guattari, 1995, s. 4)

Bilinçdışı fanteziler Lazzarato için her şeyden önce görsellikler içerisinde üretilir. Bu anlamda ticari sinema ve kapitalist toplum içerisinde üretilen bütün görsel-işitsel metalar aslında bu makinesel kölelik düzenini yeniden üretir ve özneyi faillik probleminin içerisine iter. Örneğin ticari sinema için seyircinin film izleme süreci basit bir seyirlik tüketim eylemidir; izleme sürecinde bir yorumlama, düşünsellik ifa etme ya da kavramsal tartışma gibi şeyler söz konusu değildir. Önemli olan filmin (film olduğunu hissettirmeden) seyircisi ile kendi arasında yapmış olduğu "yapıntı"lık anlaşması bozulmadan ilerlemesidir. Seyirci sinemaya bir film izlemeye geldiğini ve bunun "yapıntı" bir üretim olduğu bilinciyle girer fakat 1şıklar kapandığı andan itibaren film ile seyirci arasındaki "yapıntılık" anlaşması işler hale gelir. Bu süreç seyirci sinemadan çıktığında izlediği "şeyin" sanki gerçekten olmuş gibi hissetmesi ve büyük makinenin yeni öznelliklerinin ve semiyotikleştirme süreçlerinin bilinçaltına kazınması ile son bulur.

Nihayetinde insan öznenin sinema filmi ile olan ilişkisi de Guattiri'nin yukarıda vermiş olduğu örnekten çok farklı değildir. Birey bankamatik ile yaşadığ1 (şifre girme, çekeceği miktarı yazma, parayı bekleme, kartı alma vs.) deneyiminde (tıpkı film izleme deneyiminde olduğu

4 "Borç, borçlu öznenin ve onun "ahlak"ının yaratılmasından ayrılması mümkün olmayan ekonomik bir ilişkidir. Borç ekonomisi, klasik anlamıyla emeği "kendini işleme" ile perçinler, öyle ki ekonomi ve "etik" birlikte işlemektedir. Çağdaş "ekonomi" kavramı hem ekonomik üretimi hem de öznelliğin üretilmesini kapsar. Köklerini 19. ve 20. Asırlardaki devrimlerden alan klasik kategoriler -iş/emek, toplum ve politika- borç tarafından kat edilmiş ve büyük ölçüde yeniden tanımlanmıştır. (Lazzarato, 2015, s. 11-12) 
gibi) herhangi bir zihinselliğe ve düşünümselliğe ihtiyaç duymadan bankamatik ağının (ya da sinema-film ağının) teknik makinesinin devamlılığı için işlev gören bir aygıt/dişli gibidir.

\section{Demolition (2015) Filmi Örneğinde Başkaldırı Öznelliği ${ }^{5}$}

Demolition (Yeniden Başla, Jean Marc Vallee, 2015) filmindeki Davis karakteri makale boyunca ele alınmış olan "makinesel köleliğe" karşı bir başkaldırı öznelliğini temsil ettiği için önemlidir. Bir sinema filmi öznellik bağlamında değerlendirildiğinde, incelenebilecek 3 tür özne vardır. Filmsel gerçeklik içerisinde "eyleyen" özne yani karakter, filmi yazan (senarist), çeken (yönetmen), finansmanı sağlayan (bir anlamda üretim biçimine ve içeriğine müdahale eden-yapımc1) yani filmsel gerçekliği üreten özne(ler) ve filmsel gerçekliği alımlayan (seyirci) özne. ${ }^{6} \mathrm{Bu}$ anlamda makalenin bu bölümünde filmsel gerçeklik içerisinde eyleyen bir karakter özne olan Davis'in gerçekliğine odaklanarak onun büyük kapitalist makine karşısındaki köleliğe başkaldırısı ele alınacaktır.

Film, eşini bir trafik kazasında kaybeden ve yatırım alanında çalışan Davis Mitchell' in içinde bulunduğu psikolojik duruma odaklanır. Davis eşinin kaybıyla birlikte "kendi"sini ve hayatındaki diğer tüm şeyleri sorgulamaya ve kontrolünü yitirmeye başlar. Bir gün (eşi ameliyattayken) parasını bir oto "makineye" kaptırır ve ücret iadesi alabilmek için makinenin şirketine mektup yazmaya başlar. Yazdığı mektuplar aracılığıyla şirkette müşteri temsilcisi olarak görev yapan Karen ile tanışır ve duygusal bir yakınlaşma içerisine girer. Bu ilişki ve yaşamaya başladı̆̆ yeni hayatı, onun yaşama "yeniden başlamasına" neden olur.

İk bakışta klasik anlatı sinemasına dair kodlarla başlayan film, ilerledikçe yanılsamalar ve karakterin içerisinde bulunduğu durumlar yardımıyla karakteri parçalar ve klasik anlatı filmlerindeki bütünlüklü "özne" /"karakter" olarak karşımıza çıkan baş karakteri boşlukta salınan, ne istediği konusunda emin olamayan birisi olarak inşa eder. Her ne kadar filmde zaman, mekan ve eylem (üç birlik kuralı) tutarlı bir bütünlük sergiliyor gibi gözükse de karakter üzerinden kurulan olay örgüsü ve anlatı yapısı aynı tutarlılıkta devam etmez. Eğer karakter bütünlüklü ve tutarlı bir davranış (eylemin tutarlı olması) sergilemezse "yapıntı anlaşması" bozulmaya başlar çünkü seyircinin perdede izlediği "öznenin" ne istediğini bilen, eylemleri tutarlı olan ve bu eylemlerin sonucuna katlanabilecek olan "bütünlüklü" bir özne olması beklenir. Bakır'ın da belirtiği gibi "eğer burada temsil edilen şeyler belirli bir mantıksallık çerçevesinde verilmez ise, izleyicinin yanılsaması da bozulacaktır. Anlatı sineması temel düzeyde düşünmeye teşvik edici olmadığından dolayı yanılsamanın bozulması izlenilen filmin tatsız tuzsuz bir film olmasına yol açar." (Bakır, 2008, s. 68)

5 Başkaldırı öznelliği kavramının kökenleri makalenin birinci kısmında tartışılan "sanayi devrimi sonrası" toplumlarda bulunabilir. Özneler kitleler halinde kentlere göç etmeye başladıklarında aslında büyük bir makinesel çarkın dişlileri arasına sıkışacaklarının farkında değildirler. Bu anlamda 1900'lerin başında edebiyat (ve daha sonrasında sinemada) üretilmeye başlanan edebiyat eserleri -örneğin distopyalar- (ve bu eserlerin ürettikleri öznellikler) bölünmüş, parçalanmış fakat içinde bulunduğu sisteme karşı başkaldırmaya başlayan öznelliklerdir. Bu özneler yaşadıkları otoriter iktidarlara karşı başkaldırmaya başlar. Aynı sürecin günümüzde de yaşandığı söylenebilir. Konuyla ilgili Türkiye özelinde yapılmış bir çalışma için bkz: (Karakayali \& Yaka, 2016)

6 Makalenin bu kısmı sinemada öznelliğin nasıl ve nerede üretildiği tartışmasını yürütmeden sadece çağdaş kapitalist toplumlardaki öznellik eleştirisini film üzerinden değerlendirmeye çalışacaktır. Sinemada öznellik üretimi kısıtlılıklar açısından bu makalenin konusunun dışında kalmaktadır ve eğer değerlendirmek gerekirse sinema tarihi ile sinemada öznellik üretimi birbirine koşut bir biçimde ilerler. 1950'lerde inşa olmaya başlayan modernist sinema ile birlikte "anlatı" tartışmaları ekseninde tartışılan öznellik üretimi iki ayrı tartışma eksenine bölünür. Konuyla ilgili ilk tartışmalar Münsterberg'in çalışmalarında incelenebilir. Konuyla ilgili bir makale için bkz: (Moure, 2011) 
Anlatı sinemasının kurallarına göre "olay örgüsünü oluşturan olaylar karakterlerin eylemleri sonucu, karakterlerin eylemleri ise amaçları doğrultusunda gelişir. Karakterin hareketlerinin altında yatan neden, onu motive eden güç, güdüleyen şey 'amaç'tır." (Oluk, 2008, s. 78) Bu anlamda Davis karakteri klasik anlatı filmlerindeki gibi bir amaca sahip değildir. Genellikle bu filmlerde karakterler "yüce" bir amaca hizmet ederler fakat Demolition filminde Davis böyle bir amaca hizmet etmediği gibi günümüz öznelliklerini inşa eden tüm yapılara başkaldırmayı ve film ilerledikçe o yapıları yok etmeyi kendisine amaç edinmeye başlar.

Otomat "makinesinin" firmasına şikayet mektupları yazması Davis'in yeni bir amaç edinmesi anlamında önemlidir çünkü bu mektupları yazarken aslında karakter olarak bir iç hesaplaşmaya girmeye başlar. Öncesinde firmanın parasını aldığını ve ürünü vermediği üzerinden firma eleştirisine odaklanan mektuplar ile Davis, zaman içerisinde firma hatalarından çok kendi hatalarını görmeye ve içsel bir sorgulamaya başlar. Otomat şirketi (ya da onu temsil eden kadın) simgesel olarak Davis için bir psikolog, terapist' in yerini almaya başlar ki bu da onun yeni bir özne olma yolunda attığı adımları destekler.

Film ilk katmanda daha çok bir bireyin hayatında önemli bir olay yaşadıktan sonra yeni bir hayata yelken açması olarak okunabilir ve bu anlamda filmin sonunda karaktere bir "çözüm" önerdiği söylenebilir. Fakat film ikinci katmanda aslında bireyin kendi kimliklerini sorgulaması ve sonrasında yok etmesi üzerine kuruludur. Bunun bir sonucu olarak aslında film, Davis karakterinin iç hesaplaşması yoluyla içinde bulunduğu öznelliğe ve makinesel sisteme karşı çıkması ve yeni bir "başkaldırı öznelliği” inşa etmesi anlamına gelir.

Deleuze ve Guattari'nin bahsettiği anlamda Davis karakteri çağdaş kapitalist toplumun üretmiş olduğu öznellik modelinin prototipidir. Çok iyi bir mesleği vardır, çoğu işçinin hayalini kurduğu şekilde çok büyük bir plazada çalışır, lüks bir arabaya sahiptir, çok parası vardır ve insanların oturmak için hayatı boyunca kredi ödedikleri evlerden çok daha lüks bir evde oturur. Guattari' nin makinesel kölelik örneğine benzer bir şekilde evi dijital teknolojilerle donatılmıştır. O kadar ki evinin pencereleri bile elektronik şekilde açılır-kapanır. Evinde özne olarak gerçekleştirdiği eylem sıklıkla televizyon izlemektir ki film boyunca bu duruma sürekli vurgu yapilır.

Bir olay (Badiou) olur (trafik kazasında eşini kaybeder), zarlar atılır (Nietzsche), bir yağmur damlası sapar (Epikür) ve yıkım başlar! Davis karakterinin bir farkındalığa erişmesini sağlayan şey otomat/makinedir. Makine parayı ödemesine rağmen ona istediği şeyi (minik çikolatalar) vermez. Burada makineyi büyük kapitalist makineye/otomata alegorik olarak okumak gerekirse, Davis için bu makineden alacak bir şey kalmamıştır. Tıpkı almak istediği çikolatanın makinede sıkışması gibi, her şeye sahip olduğunu düşündüğü hayatında sıkışır kalır. David'in içsel yolculuğunun başlaması tam da çikolatanın ve kendisinin "makinesel" sistem karşısında sıkışması anına tekabül eder.

Özne (gerçek birözne, fail olma anlamında!) olarakyaptığıilk şey hayatındaki makineleri (karısı trafik kazası geçirmeden önce ona buzdolabının su damlattığı hatırlatır) parçalamak olur. Davis yıkıma öncelikle (Deleuze'ün her sabah uyandığımızda maruz kaldığımızı belirttiği) buzdolabından başlar. Buzdolabını paramparça eder. Sonrasında bir inşaatta inşaat işçilerine ücretsiz yardım ederek, yıkıma devam eder. Yıkma istenci sonlanmadığı için evine gelen kapuçino makinesi dahil olmak üzere, mutfağı, mermerleri, pencereleri, televizyonu ve "makinesel" olan her şeyi yok eder. Yıkım istenci bir türlü sönmediği için bir kepçe kiralayarak oturduğu evi tamamen yıkar! Kaybettiği eşiyle, hayatıyla, içinde oturduğu ev ile, aygıtlarla bir 
başka deyişle kendi dışındaki tüm dünya ile bir iç hesaplaşmaya girer zira sahip olduğu her şey bir anda anlamsızlaşır. Bir öznellik bunalımı yaşar ve yeni bir öznelliği inşa edebilmek için her şeyi yıkması gerekmektedir. Bu yıkımı gerçekleştirdikten sonra "gerçek" dünyaya dair bazı şeylerin farkına varmaya başlar. Ağaçları, doğayı, duygularını, hislerini, insanları, müziği ve gerçek anlamda fail olmaya dair ne varsa hepsini hissetmeye başlar.

Arabanın "makinesel asamblajı", "buzdolanın makinesel asamblajı", "elektriğin ve dijital dünyanın makinesel asamblajı", "aygıtların makinesel asamblajı" ve tüm dünyaya ilişkisi çerçevesinde büyük “kapitalist makinesel asamblaj” karakter öznenin (tam da bu yıkım esnasında gerçek bir fail olmaya başlamış ve makinesel kölelikten kurtulmuştur) doğrudan müdahalesi ile yok edilir! Böylelikle Davis aslında bu yıkım (demolition) yoluyla içinde bulunduğu düzene başkaldırır ve yeni bir öznellik inşasına doğru ilk adımı atış olur.

Bu anlamda film her ne kadar bir klasik anlatı filmi gibi doğrudan bir baş karakterin hayatına yani bir özneye odaklanıyor ve onu temsil etmeye çalışıyor gibi gözükse de bu temsiliyet karakterin kimlik ve öznellik krizinden dolayı kesin ve bütünlüklü bir hal alamaz. Anlatı filmlerinin sonu genellikle bir boşluğu, hatayı, olmaması gereken bir şeyi düzeltip olması gerektiği hale dönüştürerek sonlanır fakat Demolition filminin sonu açık uçludur. Film bu bağlamda anlatı yapısı ve olay örgüsü açısından klasik anlatı filmlerinden çok modernist anlatı filmlerine benzemektedir. Klasik anlatı filmleri sürekli olarak özdeşlik kurmak üzerine kuruludur fakat filmde Davis karakteri ile özdeşlik kurmak neredeyse imkansızdır. Özdeşlik ilkesi dramatik yapı içerisinde karakterin filmin başından sonuna kadar anlamlı ve tutarlı olacak bazı davranışları (nedensellik ilkesine de ihanet etmeden) sürdürmesi ile çalışır. Filmdeki karakterin davranışlarının hiçbirisi tutarlı değildir. Tutarlı olan tek şeyin yıkma istenci olduğu söylenebilir. Bu anlamda güçlü karakterler üzerinden inşa edilen anlatı filmlerinin aksine Demolition, kimlik/içsellik/öznellik sorunu ile mücadele eden bir karaktere odaklanmış modernist bir filmdir. 1960 sonrası Antonioni filmlerinde gördüğümüz modern toplum içerisine "sıkışmış" özne figürü bu filmde "başkaldıran özneye" dönüşmüştür.

\section{Sonuç}

Özne ve öznelik kavramlarının kökeni her ne kadar binyıllar öncesine kadar götürülse de modern öznenin inşasının Descartes ve sonrasında gelecek olan Aydınlanma ile gerçekleştiği açıktır. Bir düşünce, fikir, eyleme varlığı olarak özne ve öznellik kavramı için modernliğin eleştirilmeye başlanmasıyla birlikte en temel sorunlardan birisi "agency" yani faillik olmuştur zira eyleyen (ya da eyleme kapasitesine sahip olan) bireyler ve özneler kişilerin "kendi"leri gibi görünse de Freud'un da belirttiği gibi arka tarafta bu öznel koşulları ve bilinç durumlarını belirleyen başka faktörlerin olduğu açıtır. Özne artık günümüzde tamlığın simgesi olarak, akıl varlığı olarak, kendi ayakları üzerinde duran bir varlık olarak ele alınmamaktadır. Bu anlamda bireyler failler olarak öznedirler ancak düşünme biçimlerini, hissetme biçimlerini, (hatta sevme, algılama, duyma biçimlerini de içerek şekilde) ve eyleme geçirdikleri faaliyetleri ele aldığımızda, fail olup olmadıkları konusu tartışmaya açılır zira öznelerin eylemlerini nasıl istedikleri ya da sahip oldukları arzuları üreten bir "makinesel" sistemden söz edilebilir.

Günümüz kapitalizmi açısından öznelliği üretmek, sistem içerisindeki herhangi bir şeyi üretmekten çok daha önemlidir çünkü diğer şeylerin üretim, tüketim ve dolaşımının motoru öznellik üretimidir. Lazzarato'nun Deleuze ve Guattiri'den aktararak söylediği haliyle bu üretim toplumsal tabi kılma ve makinesel kölelik aracılığı ile gerçekleşir. Toplumsal tabi kılma modern toplumda insanları birçok kimlik (ve dolayısıyla öznellik) içerisine sokar 
ve bunu onların fark etmeyeceği şekilde dil sistemi içerisinde yapar. Zira dil bir temsil ve anlamlar dünyasıdır ve öznelerin bu anlamlar dünyasından kaçma olasılığı yok gibidir. Makinesel kölelikte ise birey şirketlerin, medyaların, okulların ve genel olarak kapitalist kurumların 'asamblajı' olarak inşa edilir. Bu düzenleme içerisinde bireyler genel olarak farklı farklı makinelerin (bütünsel olarak baktığımızda ise büyük kapitalist makinenin) yönetimi altında oldukları ve farklı makinesel parçaları oluşturdukları için bir makinesel kölelik içerisine girerler. Bu kölelik düzeni içerisinde öznelerin (her ne kadar eyleyenler olarak temsil edilseler de) kapitalist sistemin devamlılı̆̆ için yaratılmış olan diğer makinesel parçaların işlevselliklerinden çok da farkı yoktur.

Lazzarato'nun belirttiği gibi toplumsal makineler sadece hafıza, zekâ gibi kavramlar etrafında değil duyarlılık, etki, bilinçdışı fanteziler üzerinde çalışır ve bu çalışmalar genel olarak görsel-işitsel metalar aracılığı ile üretilir. Bu anlamda klasik anlatı sineması makinesel kölelik düzenini yeniden üretir ve özneyi bir faillik sorunu içinde bırakır. Nihayetinde seyircinin sinema perdesi ile ilişkisi bir bankamatik ya da diğer makinesel sistemlerle ilişkisi bakımından farklı değildir. Seyirciler sinemaya "yapıntı" bir şey izlemeye geldiklerini bilerek gelirler ve izlediklerini yanılsamanın hiç bozulmamasını isterler. Bu anlamda klasik anlatı filmlerinde yaratılan özne(karakter)'ler film hikayesi açısından bütünlüklü, amacına uygun hareket eden, arzularının peşinde koşan ve istediği her şeyi başarabilen karakterlerdir. Fakat bu durum seyircinin film, karakterin içinde bulunduğu olaylar üzerinde kendi gerçekliği üzerine düşünmesini perdeler ve seyirciyi edilgen bir hale getirir.

Demolition filmi bu bağlamda makinesel kölelik düzenine karşı çıkar. Davis karakteri, çağdaş kapitalizmin üretmiş olduğu (ve diğer öznelerin de yerinde olmayı istediği) öznelliğin simgesiyken, "makinesel" bir sıkışma sonucunda çağdaş kapitalist yaşama muhalif bir şekilde davranmaya başlar. İçinde bulunduğu özne olma halinde sıyrılır ve öznenin dünyasını altüst eder. Bu anlamda Demolition (2015) Hollywood sinemasında üretilen ve klasik öznellik biçimlerine itiraz eden, o öznenin yerine doğrudan herhangi bir öznellik ikame etmeden özneyi boşlukta bırakan önemli bir filmdir. Böylelikle film karakter üzerinde yaratmış olduğu radikal başkalaşımlar ve öznel özgürleşme yoluyla Hollywood içerisinde nadiren de olsa üretilmiş "alternatif öznellik"lerin bir temsili haline gelir.

Deleuze ve Guattariden mülhem (2006, s.121) ifade etmek gerekirse, ticari sinemanin bilinçdışı üzerindeki etkisini göz ardı etmeksizin sinema günümüzde (Demolition filminde görüldüğü gibi) çağdaş kapitalizmdeki yeni öznellik olanaklarına 1şık tutmalı ve alternatif öznellik biçimlerine odaklanmalıdır. Ticari sinemanın bilinçdışı ve harekete geçirdiği semiyotik mekanizmalar dizisinin karşısında modernist sinemanın yapması gereken, alternatif semiyotik mekanizmalar yaratmak ve "makinesel kölelik" düzenini açığa çıkarmaktır. Zira tüm hayatımızı kaplayan bu semiyotik mekanizmalar dizisi "seyircilerin semiyotikleştirme süreçlerinden" bağımsız düşünülemez. 


\section{Kaynakça}

Bakır, B. (2008). Sinema ve Psikanaliz. İstanbul: Hayalet Kitap.

Buhr, M., Schroder, W., \& Barck, K. (2006). Aydınlanma Felsefesi (çev. Veysel Atayman). İstanbul (2. Baskı): Yeni Hayat Kütüphanesi.

Deleuze, G., \& Guattari, F. (1987). A Thousand Plateus: Capitalism and Schizophrenia. London: University of Minnesota Press.

Deleuze, G., \& Guattari, F. (1993). Kapitalizm ve Şizofreni 2: Kapma Aygıtı (çev. Ali Akay). İstanbul : Bağlam Yayınları.

Foucault, M. (2014). Özne ve İktidar (çev. Işık Ergüden-Osman Akınhay). İstanbul: Ayrıntı Yayınları (4. Basım).

Guattari, F. (1995). Chaosmosis - An Ethico-Aesthetic Paradigm. Indianapolis: Indiana University Press.

Hall, D. E. (2004). Subjectivity. New York: Routledge Taylor \& Francis.

Horkheimer, M. (2018). Akıl tutulması (çev. Orhan Koçak). İstanbul: Metis Yayınları.

Karakayali, S., \& Yaka, Ö. (2016). Humor, Revolt, and Subjectivity. A. (Ed) Oberprantacher, \& A. Siclodi içinde, Subjectivation in Political Theory and Contemporary Practices (s. 203-218). Palgrave Macmillan UK.

Lazzarato, M. (2015). Borçla Yönetmek (çev. Şule Çiltaş). İstanbul: Otonom Yayıncılık.

Lazzarato, M. (2015). Borçlandırılmış İnsanın İmali (çev. Murat Erşen). İstanbul: Açılım Kitap.

Lazzarato, M. (2016). Göstergeler ve Makineler - Kapitalizm ve Öznellik Üretimi (çev. Ferda Nur Demirci). İstanbul: Otonom Yayınc1lı. Yayınları.

Mansfield, N. (2006). Öznellik - Freud`dan Harawayse Kendilik Kuramları. İzmir: Ara-lık

Moure, J. (2011). The Cinema as Art of the Mind: Hugo Münsterberg, First Theorist of Subjectivity in Film. D. Chateau içinde, Subjectivity: Filmic Representation and the Spectator's Experience (s. 23-41). Amsterdam: Amsterdam University Press.

Oluk, A. (2008). Klasik Anlatı Sineması. İstanbul: Hayalet Kitap.

Ricoeur, P. (2010). Başkası Olarak Kendisi (çev. Hakkı Hünler). Ankara: Doğu Batı Yayınları.

Rossi, A. (2018). Neoliberal Ruhlar (çev. Kürşad Kızıltuğ). Cogito - Neoliberalizmde Öznellik (Sayı: 91), 121-153. Yayınlar1.

West, D. (1998). Kısa Avrupası Felsefesine Giriş (çev. Ahmet Cevizci). İstanbul: Paradigma

Wikipedia. (2018, 10 27). Subjectivity. Wikipedia: https://en.wikipedia.org/wiki/ Subjectivity adresinden alınd 1 